\title{
Efektivitas Bokashi Berbahan Dasar Berbeda pada Pertumbuhan dan Produksi Beberapa Jenis Rumput Potong
}

\author{
Thomas Kiik ${ }^{\mathrm{a}}$, Oktovianus Rafael Nahak ${ }^{\mathrm{b}}$, dan Roberto I. C. O. Taolin ${ }^{\mathrm{c}}$ \\ ${ }^{a}$ Fakultas Pertanian, Universitas Timor, Kefamenanu, TTU - NTT, Indonesia, email: tomki8362@ gmail.com \\ ${ }^{b}$ Fakultas Pertanian, Universitas Timor, Kefamenanu, TTU - NTT, Indonesia, email: oktovianusrafael@yahoo.co.id \\ ${ }^{c}$ Fakultas Pertanian, Universitas Timor, Kefamenanu, TTU - NTT, Indonesia, email: ricotaolin@gmail.com
}

\section{Article Info}

\section{Article history:}

Received 1 April 2018

Received in revised form 19 April 2018 Accepted 21 April 2018

\section{DOI:}

https://doi.org/10.32938/ja.v3i2.527

\section{Keywords:}

Bokashi

Rumput Potong

Panicum maximun

Stenotaphrum secundatum

Pennisetum purpuphoides

\begin{abstract}
Abstrak
Sebagai rumput pertanian maka dalam pengembangan atau budidayanya rumput potong membutuhkan input berupa pupuk untuk menjamin ketersediaan unsur hara. Penelitian ini bertujuan untuk mengetahui nilai pertumbuhan dan produksi beberapa jenis rumput potong yakni rumput potong yang diberi perlakuan pupuk bokashi dengan bahan dasar berbeda. Penelitian dilaksanakan di kebun penelitian Fakultas Pertanian Universitas Timor. Penelitian berlangsung dari bulan Februari sampai akhir bulan Maret 2018. Penelitian ini menggunakan model experimen yang dengan Rancangan Acak Lengkap (RAL) pola faktorial 4x3 4 . Adapun faktor yang diuji meliputi bahan dasar bokashi yang terdiri dari 4 taraf yakni tanpa bokashi, bokashi berbahan dasar faces sapi, bokashi berbahan dasar faces ayam, dan bokashi berbahan dasar faces kambing. Faktor kedua adalah jenis rumput yang terdiri dari 3 taraf yakni Panicum maximun, Stenotaphrum secundatum, Pennisetum purpuphoides. Parameter yang diamati meliputi suhu tanah, kadar lengas tanah, $\mathrm{pH}$ tanah, berat volume tanah, tinggi tanaman, jumlah daun, berat segar daun, berat kering daun, berat segar akar, dan berat kering akar. Data dianalisis dengan anova RAL dan uji lanjut DMRT $\alpha$ 5\%. Hasil penelitian menunjukkan bahwa interaksi jenis bokashi dan jenis rumput hanya berpengaruh nyata terhadap berat volume tanah sedangkan pada parameter lain yang diamati tidak terjadi pengaruh interaksi. Jenis bokashi berpengaruh nyata terhadap parameter kadar lengas tanah, $\mathrm{pH}$ tanah, berat segar daun, berat kering daun, dan berat segar akar, sedangkan jenis rumput tidak berpengaruh nyata terhadap semua parameter yang diamati. Pemberian bokashi berbahan dasar faces kambing memberikan produks rumput berupa daun segar yang paling berat $(110,82 \mathrm{~g})$, sedangkan jenis rumput yang memiliki produksi daun segar yang paling berat adalah rumput Stenotaphrum secundatum yakni $78,03 \mathrm{~g}$.
\end{abstract}

\section{Pendahuluan}

Provinsi Nusa Tenggara Timur (NTT) merupakan pemasok ternak sapi potong ke Pulau Jawa. Namun, kemampuan tersebut makin menurun karena berbagai kendala yang dihadapi. Padang penggembalaan merupakan keunggulan dengan sistem pemeliharaan digembalakan. Namun, kualitas padang penggembalaan makin menurun (Priyanto, 2016). Hal ini menyebabkan ketersediaan pakan menjadi faktor pembatas pengembangan ternak.

Pengembangan ternak sangat ditentukan oleh daya dukung wilayah, khususnya ketersediaan pakan berupa hijauan pakan (rumput dan leguminosa). Hijauan pakan ternak dapat bersumber dari rumput alam maupun rumput yang dibudidayakan, selain dari padang penggembalaan (Priyanto, 2016).

Menurut Sudarmono (2008), bahan pakan berupa rumput bisa dibedakan atas rumput lapangan (liar) dan rumput pertanian. Rumput pertanian sengaja diusahakan dan dikembangkan untuk persediaan pakan ternak, sehingga rumput ini disebut rumput jenis unggul. Rumput atau hijauan jenis unggul bisa dibedakan lagi antara rumput potong dan rumput gembala. Yang termasuk rumput potong adalah rumput gajah (Pennisetum purpureum), rumput benggala (Pannicum maximum), rumput mexico (Euchaena mexicana), Setaria sphacelata, dan sebagainya.

Sebagai pakan ternak ruminansia dalam pengembangan atau budidayanya rumput potong membutuhkan input berupa pupuk untuk menjamin ketersediaan unsur hara. Menurut Santoso (1994), pemupukan merupakan syarat mutlak dalam membudidayakan suatu tanaman, pemupukan bertujuan untuk menggantikan unsur hara yang hilang karena proses pencucian dan pengangkutan bersama limbah pertanian.

Mahalnya harga pupuk anorganik serta pentingnya sistim pertanian berkelanjutan mengarahkan untuk pemanfaatan limbah organik yang murah, tersedia dan ramah lingkungan yang bisa digunakan sebagai pupuk organik. Bokashi merupakan salah satu jenis pupuk organik. Bokashi merupakan salah satu jenis pupuk organik yang telah mengalami proses fermentasi. Adapun kandungan Bokashi terdiri dari: N 1,25\%, P 1,02\%, K 1,44\%, KCL 7,60\%, H20 8,50\%, C 26,90\% (Sunardi, 2009 dalam Musayyanah, 2009).

Menurut (Higa \& James, 1997) bokashi adalah salah satu kata dari bahasa Jepang yang berarti bahan organik yang telah difermentasikan. Bokash dibuat dengan memfermentasikan bahan organik seperti sekam padi, jerami, serbuk gergaji atau limbah pasar. Penggunaan Effective Microorganism (EM-4) merupakan salah satu cara yang tepat untuk meningkatkan jumlah mikroorganisme di dalam tanah karena EM-4 merupakan inokulum mikroba yang dapat digunakan untuk membantu proses dekomposisi bahan organik. EM4 tidak mengandung bahan kimia yang berbahaya dan biasanya sudah tersedia di dalam tanah sehingga tidak akan merusak lingkungan. Menurut Tata (2000), pupuk bokashi merupakan bahan-bahan organik yang difermentasikan menggunakan EM-4 dapat meningkatkan tanah yang miskin unsur hara menjadi tanah yang produktif melalui proses alamiah. Sedangkan menurut Sutanto (2002), mikroorganisme efektif (EM) merupakan kultur campuran berbagai jenis mikroorganisme yang bermanfaat (bakteri fotosintetik, bakteri asam laktat, ragi, actinomycetes dan jamur peragian) yang dapat dimanfaatkan sebagai inokulan untuk meningkatkan keragaman mikrobia tanah. Pupuk organik bokashi dibuat dari bahan-bahan organik seperti jerami, sampah organik, pupuk kandang, sekam padi, rumput dan limbah jamur merang yang telah difermentasikan oleh Effective Microorganisme (EM).

Berbagai penelitian telah membuktikan bahwa bokashi memberikan pengaruh pada pertumbuhan dan produksi rumput potong. Penelitian (Kusuma, 2013) menyimpulkan bahwa pemberian dosis bokashi memberikan pengaruh terhadap jumlah anakan umur 8 minggu setelah tanam (MST), tinggi tanaman dan jumlah daun umur 4 MST, 6 MST dan 8 MST, serta produksi rumput gajah.

Kegiatan pemupukan tanaman harus mempertimbangkan faktor-faktor antara lain tanaman yang akan dipupuk, jenis pupuk yang digunakan, dosis pupuk, cara aplikasi pupuk dan waktu pemupukan. Bokashi yang dibuat dengan bahan dasar yang berbeda akan memberikan respon yang berbeda terhadap pertumbuhan dan produksi tanaman karena kualitas bokashi yang dihasilkan juga berbeda. (Kusuma, 2012) membuktikan bahwa beberapa jenis pupuk kandang sebagai bahan dasar berpengaruh terhadap kualitas bokashi diantaranya terdapat perbedaan kandungan unsur hara $\mathrm{P}$ dan $\mathrm{K}$ yang signifikan, sedangkan dari segi warna, bau dan tekstur tidak jauh berbeda dari warna, bau dan tekstur bahan asalnya.

Tujuan dari penelitian ini untuk mengetahui nilai pertumbuhan dan produksi beberapa jenis rumput potong yakni rumput Panicum maximun, Stenotaphrum secundatum, dan Pennisetum purpuphoides yang diberi perlakuan pupuk bokashi dengan bahan dasar berbeda.

\section{Metode Penelitian}

Penelitian dilaksanakan di kebun penelitian Fakultas Pertanian Universitas Timor, Kelurahan Sasi Kecamatan Kota Kefamenanu, Kabupaten Timor Tengah Utara, Provinsi Nusa Tenggara Timur. Penelitian berlangsung selama satu periode produksi (35) hari dimulai dari bulan Februari sampai akhir bulan Maret 2018. Penelitian ini menggunakan model experimen yang menggunakan Rancangan Acak Lengkap (RAL) pola faktorial 4x3x4 (Steel \& Torrie, 1981). Adapun faktor yang diuji meliputi:

Faktor I. Bahan dasar Bokashi yang terdiri dari 4 taraf yakni:

$$
\begin{array}{ll}
\mathrm{B}_{0} & =\text { Tanpa Bokashi } \\
\mathrm{B}_{1} & =\text { Bokashi berbahan dasar faces sapi } \\
\mathrm{B}_{2} & =\text { Bokashi berbahan dasar faces ayam } \\
\mathrm{B}_{3} & =\text { Bokashi berbahan dasar faces kambing }
\end{array}
$$

Faktor II. Jenis Rumput yang terdiri dari 3 taraf yakni:

$$
\begin{array}{ll}
\mathrm{J}_{1} & =\text { Rumput Panicum maximum } \\
\mathrm{J}_{2} & =\text { Rumput Stenotaphrum secundatum } \\
\mathrm{J}_{3} & =\text { Rumput Pennisetum purpuphoides }
\end{array}
$$

Dari ke dua faktor di atas dihasilkan 12 kombinasi perlakuan yang terdiri dari $b_{0} r_{1}, b_{0} r_{2}, b_{0} r_{3}, b_{1} r_{1}, b_{1} r_{2}, b_{1} r_{3}, b_{2} r_{1}, b_{2} r_{2}, b_{2} r_{3}, b_{3} r_{1}, b_{3} r_{2}, b_{3} r_{3}$. Setiap kombinasi diulang 3 kali sehingga terdapat 36 satuan percobaan.

Tempat penelitian berupa tiga buah bale-bale dengan ukurannya tingg $100 \mathrm{~cm}$, yang ditempatkan pada lahan berukuran 3,3 m x 3,3 m. Pada setiap balebale ditempatkan 12 buah ember plastik sebagai unit percobaan dengan jarak antara setiap unit percobaan $30 \mathrm{~cm}$. Pada setiap unit percobaan diberikan label perlakuan.

Bokashi disiapkan sebanyak $90 \mathrm{~kg}$ dengan perincian bokashi faces sapi sebanyak $30 \mathrm{~kg}$, bokashi faces ayam sebanyak $30 \mathrm{~kg}$, dan bokashi faces kambing sebanyak $30 \mathrm{~kg}$. Pembuatan bokashi dilakukan dengan langkah-langkah sebagai berikut:

- Larutkan gula pasir dan larutan EM-4 dalam air

- Faces, sekam padi dan dedak dicampur merata kemudian digundukan di atas lantai yang kering di tempat yang memiliki atap.

Adonan diaduk rata dan digundukan.

- Siramkan larutan gula dan EM-4 perlahan-lahan ke dalam adonan secara merata hingga bila adonan dikepal, air tidak menetes dan bila kepalan tangan dilepas maka adonan tidak pecah.

Kemudian ditutup plastik atau karung goni selama 4 - 7 hari 
- Pertahankan suhu adonan maksimal $50^{\circ} \mathrm{C}$, bila suhunya lebih maka turunkan dengan membolak-balik adonan. Pemeriksaan suhu dilakukan setiap 5 jam sekali.

- Setelah 4 - 7 hari, Bokashi telah selesai terfermentasi dan siap digunakan. Media tanam yang digunakan adalah bokashi yang telah disiapkan.

Bokashi kemudian dimasukkan ke dalam setiap unit percobaan dengan volume yang sama. Penempatan bokashi dalam unit percobaan disesuaikan antara jenis bahan bokashi dengan label perlakuan yang telah ditempel pada unit percobaan. Pada unit percobaan yang mendapat perlakuan tanpa bokashi hanya diberikan campuran tanah dan pupuk kandang.

Penanaman dilakukan serempak pada semua unit percobaan pada sore hari dengan cara ditugal sedalam $3 \mathrm{~cm}$. Jumlah bibit per unit percobaan adalah 1 bibit. Penanaman setiap jenis rumput pada unit percobaan disesuaikan dengan label perlakuan yang telah ditempel.

Penyiraman dilakukan dua kali sehari yaitu pagi dan sore menggunakan gembor dengan volume air yang diberikan seragam pada setiap tanaman. Penyiangan dilakukan untuk mengurangi atau membersihkan gulma dan sejenis tumbuhan lain yang merupakan pengganggu tanaman menggunakan tajak. Variabel yang diamati dalam penelitian ini meliputi:

a. Suhu Tanah $\left({ }^{\circ} \mathrm{C}\right)$

Pengukuran suhu tanah dilakukan saat tanaman berumur 35 hari setelah tanam (HST), menggunakan termometer suhu tanah, dengan cara ditancapkan pada kedalaman tanah $5 \mathrm{~cm}$ selama 3 menit pada setiap unit percobaan. Pengukuran dilakukan pada siang hari pukul 12.00-14.00 WITA.

b. Kadar Lengas Tanah (\%)

Sampel tanah diambil dari setiap unit percobaan dengan volume tertentu. Sampel tanah yang sudah diambil, disimpan dalam wadah plastik yang ditandai dengan label, kemudian ditimbang untuk mengetahui berat basah, selanjutnya tanah dioven selama 48 jam pada suhu $105^{\circ} \mathrm{C}$, kemudian ditimbang untuk mengetahui berat kering. Pengukuran dilakukan saat tanaman berumur 35 HST. c. $\mathrm{pH}$ Tanah

$\mathrm{pH}$ tanah diukur menggunakan $\mathrm{pH}$ tester pada saat tanaman berumur 35 HST. Pengukuran dilakukan pada tanah dari setiap unit percobaan.

d. Berat Volume Tanah

Sampel tanah kering dari pengukuran kadar lengas tanah kemudian diikat dengan tali raffia sepanjang $10 \mathrm{~cm}$ dan dicelupkan ke dalam cairan lilin dalam wadah aluminium yang dipanaskan dengan lampu spritus. Gumpalan tanah yang telah dilapisi lilin dicelupkan ke dalam gelas ukur berisi air setinggi $40 \mathrm{ml}$. kenaikan volume air dihitung sebagai volume tanah.

e. Tinggi Tanaman $(\mathrm{cm})$

Tinggi tanaman diukur dari pangkal tanaman sampai ujung daun paling tinggi, pengukuran menggunakan penggaris centimeter. Pengukuran dilakukan pada setiap unit percobaan pada saat tanaman berumur 35 HST.

f. Jumlah Daun (helai)

Jumlah daun diperoleh dengan cara menghitung semua daun yang terbentuk pada setiap tanaman saat tanaman berumur 35 HST.

g. Berat Segar Tajuk Tanaman (g)

Pengukuran berat segar tajuk dilakukan pada akhir penelitian menggunakan timbangan analitik. Bagian tanaman di atas permukaan tanah (bagian tajuk) setelah panen (35 HST), dipotong, dicuci, ditiriskan selanjutnya ditimbang.

h. Berat Kering Tajuk Tanaman (g)

Berat kering tajuk diperoleh dari penimbangan bagian tajuk tanaman yang telah dioven pada suhu $70^{\circ} \mathrm{C}$ selama 48 jam hingga mencapai berat konstan.

i. Berat Segar Akar (g)

Seluruh bagian akar yang dibersihkan dari tanah, dicuci dengan air, ditiriskan dan timbang dengan timbangan analitik.

j. $\quad$ Berat Kering Akar (g)

Setelah penimbangan berat segar akar dilanjutkan dengan mengeringkan akar tanaman dalam oven dengan suhu $70^{\circ} \mathrm{C}$ selama 48 jam hingga mencapai berat konstan. Selanjutnya akar yang telah kering ditimbang menggunakan timbangan analitik.

k. Berat Segar Tanaman $(\mathrm{g})$

Berat segar tanaman diukur dengan cara dari menjumlahkan berat segar tajuk dan berat segar akar.

1. Berat Kering Tanaman (g)

Berat kering tanaman diukur dengan cara dari menjumlahkan berat kering tajuk dan berat kering akar.

Semua data yang diperoleh ditabulasikan kemudian dianalisis dengan menggunakan sidik ragam (Anova) Rancangan Acak Lengkap (RAL), selanjutnya untuk mengetahui pengaruh perlakuan yang diberikan, rata-rata perlakuan diuji lanjut menggunakan Duncan Multiple Range Test (DMRT) pada a $5 \%$ sesuai petunjuk (Gomez \& Gomez, 1984). Analisis data menggunakan program SAS 9.1.

\section{Hasil dan Pembahasan \\ 3.1 Suhu Tanah}

Hasil sidik ragam (anova) menunjukkan tidak terjadi pengaruh interaksi antara jenis bokashi dan jenis rumput terhadap suhu tanah. Jenis bokashi tidak berpengaruh nyata terhadap suhu tanah tetapi tanah yang diberikan bokashi yang berbahan dasar faces kambing cenderung memiliki suhu tanah yang lebih rendah dibanding suhu tanah yang diberikan bokashi dengan bahan dasar faces sapi, ayam maupun tanah yang tidak diberikan bokashi.

Jenis rumput juga tidak berpengaruh nyata terhadap suhu tanah tetapi data pada Tabel 1. menunjukkan bahwa suhu tanah yang ditanami rumput Pennisetum purpuphoides cenderung lebih rendah dibandingkan rumput Panicum maximun dan rumput Stenotaphrum secundatum.

Tabel 1. Suhu Tanah $\left({ }^{\circ} \mathrm{C}\right)$

\begin{tabular}{lcccc}
\hline \multirow{2}{*}{$\begin{array}{c}\text { Jenis } \\
\text { Bokashi (B) }\end{array}$} & $\begin{array}{c}\text { Panicum } \\
\text { maximun }\end{array}$ & $\begin{array}{c}\text { Stenotaphrum } \\
\text { secundatum }\end{array}$ & $\begin{array}{c}\text { Pennisetum } \\
\text { purpuphoides }\end{array}$ & Rerata \\
\hline Kontrol & 37,22 & 36,91 & 36,96 & $37,03^{\mathrm{a}}$ \\
Sapi & 37,16 & 37,00 & 36,94 & $37,03^{\mathrm{a}}$ \\
Kambing & 36,61 & 36,86 & 36,82 & $36,76^{\mathrm{a}}$ \\
Ayam & 37,24 & 36,57 & 36,57 & $36,79^{\mathrm{a}}$ \\
\hline Rerata & $37,06^{\mathrm{a}}$ & $36,83^{\mathrm{a}}$ & $36,82^{\mathrm{a}}$ & $(-)$ \\
\hline Ketennnnn
\end{tabular}

Keterangan: Angka superscript pada baris dan kolom yang diikuti dengan huruf yang sama tidak berbeda nyata menurut uji DMRT $\alpha 5 \%$. ( - ): Tidak terjadi interaksi antar faktor.

\subsection{Kadar Lengas Tanah}

Hasil sidik ragam (anova) menunjukkan tidak terjadi pengaruh interaksi antara jenis bokashi dan jenis rumput terhadap kadar lengas tanah. Jenis bokashi berpengaruh nyata terhadap kadar lengas tanah dimana tanah yang diberikan bokashi yang berbahan dasar faces kambing memiliki kadar lengas paling tinggi dan berbeda nyata dengan kadar lengas tanah yang tidak diberikan bokashi tetapi tidak berbeda nyata dengan kadar lengas tanah yang diberikan bokashi dengan bahan dasar faces sapi atau ayam.

\section{Tabel 2. Kadar Lengas Tanah (\%)}

\begin{tabular}{lcccc}
\hline \multirow{2}{*}{$\begin{array}{c}\text { Jenis } \\
\text { Bokashi (B) }\end{array}$} & \multicolumn{3}{c}{ Jenis Rumput (J) } & \\
\cline { 2 - 4 } & $\begin{array}{c}\text { Panicum } \\
\text { maximun }\end{array}$ & $\begin{array}{c}\text { Stenotaphrum } \\
\text { secundatum }\end{array}$ & $\begin{array}{c}\text { Pennisetum } \\
\text { purpuphoides }\end{array}$ & Rerata \\
\hline Kontrol & 33,77 & 32,77 & 27,05 & $31,20^{\mathrm{b}}$ \\
Sapi & 40,61 & 37,05 & 36,13 & $37,93^{\mathrm{ab}}$ \\
Kambing & 45,00 & 41,59 & 35,76 & $40,78^{\mathrm{a}}$ \\
Ayam & 30,53 & 40,78 & 38,38 & $36,56^{\mathrm{ab}}$ \\
\hline Rerata & $37,48^{\mathrm{a}}$ & $38,05^{\mathrm{a}}$ & $34,33^{\mathrm{a}}$ & $(-)$ \\
\hline
\end{tabular}

Keterangan: Angka superscript pada baris dan kolom yang diikuti dengan huruf yang sama tidak berbeda nyata menurut uji DMRT $\alpha 5 \%$. ( - ): Tidak terjadi interaksi antar faktor.

Jenis rumput tidak berpengaruh nyata terhadap kadar lengas tanah tetapi data pada Tabel 2. menunjukkan bahwa kadar lengas tanah yang ditanami rumput Stenotaphrum secundatum cenderung lebih tinggi dibandingkan rumput Panicum maximun dan rumput Pennisetum purpuphoides.

\section{3 pH Tanah}

Hasil sidik ragam (anova) menunjukkan tidak terjadi pengaruh interaks antara jenis bokashi dan jenis rumput terhadap $\mathrm{pH}$ tanah. Jenis bokashi berpengaruh nyata terhadap $\mathrm{pH}$ tanah dimana tanah yang diberikan bokashi yang berbahan dasar faces kambing memiliki $\mathrm{pH}$ yang paling rendah dan berbeda nyata dengan $\mathrm{pH}$ tanah yang diberikan bokashi dengan bahan dasar faces sapi atau ayam maupun tanah yang tidak diberikan bokashi.

\section{Tabel 3. pH Tanah}

\begin{tabular}{lcccc}
\hline \multirow{2}{*}{$\begin{array}{c}\text { Jenis } \\
\text { Bokashi (B) }\end{array}$} & $\begin{array}{c}\text { Panicum } \\
\text { maximun }\end{array}$ & $\begin{array}{c}\text { Stenotaphrum } \\
\text { secundatum }\end{array}$ & $\begin{array}{c}\text { Pennisetum } \\
\text { purpuphoides }\end{array}$ & Rerata \\
\hline Kontrol & 7,37 & 7,64 & 7,69 & $7,57^{\mathrm{a}}$ \\
Sapi & 7,63 & 7,56 & 7,33 & $7,51^{\mathrm{a}}$ \\
Kambing & 7,13 & 7,06 & 7,09 & $7,09^{\mathrm{b}}$ \\
Ayam & 7,30 & 7,37 & 7,48 & $7,38^{\mathrm{a}}$ \\
\hline Rerata & $7,36^{\mathrm{a}}$ & $7,41^{\mathrm{a}}$ & $7,40^{\mathrm{a}}$ & $(-)$ \\
\hline
\end{tabular}

Keterangan: Angka superscript pada baris dan kolom yang diikuti dengan huruf yang sama tidak berbeda nyata menurut uji DMRT $\alpha 5 \%$. ( - ): Tidak terjadi interaksi antar faktor.

Jenis rumput tidak berpengaruh nyata terhadap $\mathrm{pH}$ tanah tetapi data pada Tabel 3. menunjukkan bahwa $\mathrm{pH}$ tanah yang ditanami rumput Panicum maximun cenderung lebih mendekati $\mathrm{pH}$ netral (7) dibandingkan rumput Stenotaphrum secundatum dan rumput Pennisetum purpuphoides.

\subsection{Berat Volume Tanah}

Hasil sidik ragam (anova) menunjukkan bahwa interaksi antara jenis bokashi dan jenis rumput berpengaruh nyata terhadap berat volume tanah.

Jenis bokashi tidak berpengaruh nyata terhadap berat volume tanah tetapi tanah yang tidak diberikan bokashi cenderung memiliki berat volume tanah yang lebih rendah dibanding berat volume tanah yang diberikan bokashi dengan bahan dasar faces sapi, ayam maupun kambing.

Jenis rumput juga tidak berpengaruh nyata terhadap berat volume tanah tetapi data pada Tabel 4. menunjukkan bahwa berat volume tanah yang ditanami 
rumput Pennisetum purpuphoides cenderung lebih rendah atau tanah lebih gembur dibandingkan rumput Stenotaphrum secundatum dan rumput Panicum maximun.

Tabel 4. Berat Volume Tanah $\left(\mathrm{g} / \mathrm{cm}^{3}\right)$

\begin{tabular}{lcccc}
\hline \multirow{2}{*}{$\begin{array}{c}\text { Jenis } \\
\text { Bokashi (B) }\end{array}$} & $\begin{array}{c}\text { Panicum } \\
\text { maximun }\end{array}$ & $\begin{array}{c}\text { Stenotaphrum } \\
\text { secundatum }\end{array}$ & $\begin{array}{c}\text { Pennisetum } \\
\text { purpuphoides }\end{array}$ & Rerata \\
\hline Kontrol & 0,74 & 0,87 & 1,02 & $0,87^{\mathrm{a}}$ \\
Sapi & 1,45 & 1,01 & 0,74 & $1,07^{\mathrm{a}}$ \\
Kambing & 0,87 & 0,67 & 1,11 & $0,88^{\mathrm{a}}$ \\
Ayam & 1,15 & 1,57 & 0,79 & $1,17^{\mathrm{a}}$ \\
\hline Rerata & $1,05^{\mathrm{a}}$ & $1,03^{\mathrm{a}}$ & $0,92^{\mathrm{a}}$ & $(+)$ \\
\hline
\end{tabular}

Keterangan: Angka superscript pada baris dan kolom yang diikuti dengan huruf yang sama tidak berbeda nyata menurut uji DMRT $\alpha 5 \%$. $(+)$ : Terjadi interaksi antar faktor.

\subsection{Tinggi Tanaman}

Hasil sidik ragam (anova) menunjukkan tidak terjadi pengaruh interaksi antara jenis bokashi dan jenis rumput terhadap tinggi tanaman. Jenis bokashi tidak berpengaruh nyata terhadap tinggi tanaman tetapi tanaman yang diberikan bokashi yang berbahan dasar faces kambing cenderung lebih tinggi dibanding tanaman yang diberikan bokashi dengan bahan dasar faces sapi, ayam maupun tanaman yang tidak diberikan bokashi.

$\underline{\text { Tabel 5. Tinggi Tanaman }(\mathrm{cm})}$

\begin{tabular}{lcccc}
\hline \multirow{2}{*}{$\begin{array}{c}\text { Jenis } \\
\text { Bokashi (B) }\end{array}$} & $\begin{array}{c}\text { Panicum } \\
\text { maximun }\end{array}$ & $\begin{array}{c}\text { Stenotaphrum } \\
\text { secundatum }\end{array}$ & $\begin{array}{c}\text { Pennisetum } \\
\text { purpuphoides }\end{array}$ & Rerata \\
\hline Kontrol & 66,33 & 60,42 & 62,42 & $63,06^{\mathrm{a}}$ \\
Sapi & 66,17 & 68,33 & 54,33 & $62,94^{\mathrm{a}}$ \\
Kambing & 80,33 & 89,33 & 86,00 & $85,22^{\mathrm{a}}$ \\
Ayam & 84,00 & 71,83 & 88,17 & $81,33^{\mathrm{a}}$ \\
\hline Rerata & $74,21^{\mathrm{a}}$ & $72,48^{\mathrm{a}}$ & $72,73^{\mathrm{a}}$ & $(-)$
\end{tabular}

Keterangan: Angka superscript pada baris dan kolom yang diikuti dengan huruf yang sama tidak berbeda nyata menurut uji DMRT $\alpha 5 \%$. ( - ): Tidak terjadi interaksi antar faktor.

Jenis rumput juga tidak berpengaruh nyata terhadap tinggi tanaman tetapi data pada Tabel 5. menunjukkan bahwa rumput Panicum maximun cenderung lebih tinggi dibandingkan rumput Stenotaphrum secundatum dan rumput Pennisetum purpuphoides.

\subsection{Jumlah Anakan}

Hasil sidik ragam (anova) menunjukkan tidak terjadi pengaruh interaksi antara jenis bokashi dan jenis rumput terhadap jumlah anakan. Jenis bokashi tidak berpengaruh nyata terhadap jumlah anakan tetapi tanaman yang diberikan bokashi yang berbahan dasar faces kambing cenderung memiliki anakan yang lebih banyak dibanding anakan tanaman yang diberikan bokashi dengan bahan dasar faces sapi, ayam maupun tanaman yang tidak diberikan bokashi.

Tabel 6. Jumlah Anakan

\begin{tabular}{lcccc}
\hline \multirow{2}{*}{$\begin{array}{c}\text { Jenis } \\
\text { Bokashi (B) }\end{array}$} & \multicolumn{3}{c}{ Jenis Rumput (J) } & \multirow{2}{*}{ Rerata } \\
\cline { 2 - 4 } & maximum & $\begin{array}{c}\text { Stenotaphrum } \\
\text { secundatum }\end{array}$ & $\begin{array}{c}\text { Pennisetum } \\
\text { purpuphoides }\end{array}$ & \\
\hline Kontrol & 5,33 & 4,50 & 4,83 & $4,89^{\mathrm{a}}$ \\
Sapi & 7,17 & 6,67 & 6,17 & $6,67^{\mathrm{a}}$ \\
Kambing & 7,83 & 8,83 & 10,00 & $8,89^{\mathrm{a}}$ \\
Ayam & 10,83 & 6,33 & 7,67 & $8,28^{\mathrm{a}}$ \\
\hline Rerata & $7,79^{\mathrm{a}}$ & $6,58^{\mathrm{a}}$ & $7,17^{\mathrm{a}}$ & $(-)$
\end{tabular}

Keterangan: Angka superscript pada baris dan kolom yang diikuti dengan huruf yang sama tidak berbeda nyata menurut uji DMRT $\alpha 5 \%$. ( - ): Tidak terjadi interaksi antar faktor.

Jenis rumput juga tidak berpengaruh nyata terhadap jumlah anakan tetapi data pada Tabel 6. menunjukkan bahwa rumput Panicum maximun cenderung memiliki anakan yang lebih banyak dibandingkan rumput Stenotaphrum secundatum dan rumput Pennisetum purpuphoides.

\subsection{Jumlah Daun}

Hasil sidik ragam (anova) menunjukkan tidak terjadi pengaruh interaksi antara jenis bokashi dan jenis rumput terhadap jumlah daun.

Jenis bokashi tidak berpengaruh nyata terhadap jumlah daun tetapi tanaman yang diberikan bokashi yang berbahan dasar faces kambing cenderung memiliki daun yang lebih banyak dibanding daun tanaman yang diberikan bokashi dengan bahan dasar faces sapi, ayam maupun tanaman yang tidak diberikan bokashi.

Jenis rumput juga tidak berpengaruh nyata terhadap jumlah daun tetapi data pada Tabel 7. menunjukkan bahwa rumput Panicum maximun cenderung memiliki daun yang lebih banyak dibandingkan rumput Stenotaphrum secundatum dan rumput Pennisetum purpuphoides.

\begin{tabular}{lcccc} 
Tabel 7. Jumlah Daun & \multicolumn{3}{c}{} \\
\hline \multirow{2}{*}{$\begin{array}{c}\text { Jenis } \\
\text { Bokashi (B) }\end{array}$} & $\begin{array}{c}\text { Panicum } \\
\text { maximun }\end{array}$ & $\begin{array}{c}\text { Stenotaphrum } \\
\text { secundatum }\end{array}$ & $\begin{array}{c}\text { Pennisetum } \\
\text { purpuphoides }\end{array}$ & Rerata \\
\hline Kontrol & 31,17 & 31,83 & 32,00 & $31,67^{\mathrm{a}}$ \\
Sapi & 37,00 & 38,67 & 32,67 & $36,11^{\mathrm{a}}$ \\
Kambing & 47,00 & 48,50 & 50,50 & $48,67^{\mathrm{a}}$ \\
Ayam & 48,67 & 36,67 & 40,33 & $41,89^{\mathrm{a}}$ \\
\hline Rerata & $40,96^{\mathrm{a}}$ & $38,92^{\mathrm{a}}$ & $38,88^{\mathrm{a}}$ & $(-)$ \\
\hline
\end{tabular}

Keterangan: Angka superscript pada baris dan kolom yang diikuti dengan huruf yang sama tidak berbeda nyata menurut uji DMRT $\alpha 5 \%$. ( - ): Tidak terjadi interaksi antar faktor.

\subsection{Berat Segar Daun}

Hasil sidik ragam (anova) menunjukkan tidak terjadi pengaruh interaksi antara jenis bokashi dan jenis rumput terhadap berat segar daun.

Tabel 8. Berat Segar Daun $(\mathrm{g})$

\begin{tabular}{lcccc}
\hline \multirow{2}{*}{$\begin{array}{c}\text { Jenis } \\
\text { Bokashi (B) }\end{array}$} & $\begin{array}{c}\text { Panicum } \\
\text { maximun }\end{array}$ & $\begin{array}{c}\text { Stenotaphrum } \\
\text { secundatum }\end{array}$ & $\begin{array}{c}\text { Pennisetum } \\
\text { purpuphoides }\end{array}$ & Rerata \\
\hline Kontrol & 23,63 & 33,21 & 24,88 & $27,24^{\mathrm{c}}$ \\
Sapi & 55,51 & 70,27 & 46,04 & $57,27^{\mathrm{cb}}$ \\
Kambing & 94,38 & 131,56 & 106,50 & $110,82^{\mathrm{a}}$ \\
Ayam & 83,07 & 77,09 & 62,87 & $74,34^{\mathrm{b}}$ \\
\hline Rerata & $64,15^{\mathrm{a}}$ & $78,03^{\mathrm{a}}$ & $60,07^{\mathrm{a}}$ & $(-)$ \\
\hline Keterangan: Angka superscript pada baris dan kolom yang diikuti dengan huruf \\
\\
& yang sama tidak berbeda nyata menurut uji DMRT $\alpha$ & $\alpha \% .(-)$ : \\
& Tidak terjadi interaksi antar faktor.
\end{tabular}

Jenis bokashi berpengaruh nyata terhadap berat segar daun dimana tanaman yang diberikan bokashi yang berbahan dasar faces kambing memiliki berat segar daun yang paling berat dan berbeda nyata dengan berat kering daun tanaman yang diberikan bokashi dengan bahan dasar faces sapi atau ayam maupun tanaman yang tidak diberikan bokashi. Jenis rumput tidak berpengaruh nyata terhadap berat segar daun tetapi data pada Tabel 8. menunjukkan bahwa rumput Stenotaphrum secundatum cenderung memiliki daun segar yang lebih berat dibandingkan rumput Panicum maximun dan rumput Pennisetum purpuphoides.

\subsection{Berat Kering Daun}

Hasil sidik ragam (anova) menunjukkan tidak terjadi pengaruh interaksi antara jenis bokashi dan jenis rumput terhadap berat kering daun. Jenis bokashi berpengaruh nyata terhadap berat kering daun dimana tanaman yang diberikan bokashi yang berbahan dasar faces kambing memiliki berat kering daun yang paling berat dan berbeda nyata dengan berat kering daun tanaman yang diberikan bokashi dengan bahan dasar faces sapi dan tanaman yang tidak diberikan bokashi tetapi tidak berbeda nyata dengan berat kering daun tanaman yang diberikan bokashi dengan bahan dasar faces ayam.

Tabel 9. Berat Kering Daun (g)

\begin{tabular}{lcccc}
\hline \multirow{2}{*}{$\begin{array}{c}\text { Jenis } \\
\text { Bokashi (B) }\end{array}$} & $\begin{array}{c}\text { Panicum } \\
\text { maximun }\end{array}$ & $\begin{array}{c}\text { Stenotaphrum } \\
\text { secundatum }\end{array}$ & $\begin{array}{c}\text { Pennisetum } \\
\text { purpuphoides }\end{array}$ & Rerata \\
\hline Kontrol & 5,19 & 6,78 & 5,39 & $5,79^{\mathrm{c}}$ \\
Sapi & 12,10 & 10,66 & 9,53 & $10,77^{\mathrm{cb}}$ \\
Kambing & 15,36 & 25,78 & 19,18 & $20,11^{\mathrm{a}}$ \\
Ayam & 17,60 & 15,88 & 13,49 & $15,66^{\mathrm{ab}}$ \\
\hline Rerata & $12,56^{\mathrm{a}}$ & $14,78^{\mathrm{a}}$ & $11,90^{\mathrm{a}}$ & $(-)$ \\
\hline
\end{tabular}

Keterangan: Angka superscript pada baris dan kolom yang diikuti dengan huruf yang sama tidak berbeda nyata menurut uji DMRT $\alpha 5 \%$. ( - ): Tidak terjadi interaksi antar faktor.

Jenis rumput tidak berpengaruh nyata terhadap berat kering daun tetapi data pada Tabel 9. menunjukkan bahwa rumput Stenotaphrum secundatum cenderung memiliki berat kering daun yang lebih berat dibandingkan rumput Panicum maximun dan rumput Pennisetum purpuphoides.

\subsection{Berat Segar Akar}

Hasil sidik ragam (anova) menunjukkan tidak terjadi pengaruh interaksi antara jenis bokashi dan jenis rumput terhadap berat segar akar.

Jenis bokashi berpengaruh nyata terhadap berat segar akar dimana tanaman yang diberikan bokashi yang berbahan dasar faces kambing memiliki berat akar segar yang paling berat dan berbeda nyata dengan berat segar akar tanaman yang diberikan bokashi dengan bahan dasar faces sapi dan tanaman yang tidak diberikan bokashi tetapi tidak berbeda nyata dengan berat segar akar tanaman yang diberikan bokashi dengan bahan dasar faces ayam.

Jenis rumput tidak berpengaruh nyata terhadap berat segar akar tetapi data pada Tabel 10. menunjukkan bahwa rumput Panicum maximun cenderung memiliki akar segar yang lebih berat dibandingkan rumput Stenotaphrum secundatum dan rumput Pennisetum purpuphoides. 
Tabel 10. Berat Segar Akar (g)

\begin{tabular}{lcccc}
\hline \multirow{2}{*}{$\begin{array}{c}\text { Jenis } \\
\text { Bokashi (B) }\end{array}$} & \multicolumn{3}{c}{ Jenis Rumput $(\mathrm{J})$} & Rerata \\
\cline { 2 - 4 } & $\begin{array}{c}\text { Panicum } \\
\text { maximun }\end{array}$ & $\begin{array}{c}\text { Stenotaphrum } \\
\text { secundatum }\end{array}$ & $\begin{array}{c}\text { Pennisetum } \\
\text { purpuphoides }\end{array}$ & \\
\hline Kontrol & 14,36 & 27,95 & 22,24 & $21,51^{\mathrm{b}}$ \\
Sapi & 27,61 & 27,39 & 26,24 & $27,08^{\mathrm{b}}$ \\
Kambing & 88,70 & 51,03 & 40,92 & $60,22^{\mathrm{a}}$ \\
Ayam & 45,66 & 34,37 & 46,61 & $42,21^{\mathrm{ab}}$ \\
\hline Rerata & $44,08^{\mathrm{a}}$ & $35,18^{\mathrm{a}}$ & $34,00^{\mathrm{a}}$ & $(-)$ \\
\hline
\end{tabular}

Keterangan: Angka superscript pada baris dan kolom yang diikuti dengan huruf yang sama tidak berbeda nyata menurut uji DMRT $\alpha 5 \%$. ( - ) Tidak terjadi interaksi antar faktor.

\subsection{Berat Kering Akar}

Hasil sidik ragam (anova) menunjukkan tidak terjadi pengaruh interaks antara jenis bokashi dan jenis rumput terhadap berat kering akar. Jenis bokashi tidak berpengaruh nyata terhadap berat kering akar tetapi tanaman yang diberikan bokashi yang berbahan dasar faces kambing cenderung memiliki berat kering akar yang lebih berat dibanding berat kering akar tanaman yang diberikan bokashi dengan bahan dasar faces sapi, ayam maupun tanaman yang tidak diberikan bokashi.

Jenis rumput juga tidak berpengaruh nyata terhadap berat kering akar tetapi data pada Tabel 11. menunjukkan bahwa rumput Panicum maximun cenderung memiliki berat kering akar yang lebih berat dibandingkan rumput Stenotaphrum secundatum dan rumput Pennisetum purpuphoides.

$\underline{\text { Tabel 11. Berat Kering Akar (g) }}$

\begin{tabular}{|c|c|c|c|c|}
\hline \multirow{2}{*}{$\begin{array}{c}\text { Jenis } \\
\text { Bokashi (B) }\end{array}$} & \multicolumn{3}{|c|}{ Jenis Rumput (J) } & \multirow[b]{2}{*}{ Rerata } \\
\hline & $\begin{array}{l}\text { Panicum } \\
\text { maximun }\end{array}$ & $\begin{array}{l}\text { Stenotaphrum } \\
\text { secundatum }\end{array}$ & $\begin{array}{c}\text { Pennisetum } \\
\text { purpuphoides }\end{array}$ & \\
\hline Kontrol & 5,42 & 8,05 & 13,24 & $8,90^{\mathrm{a}}$ \\
\hline Sapi & 15,97 & 12,69 & 14,10 & $14,25^{\mathrm{a}}$ \\
\hline Kambing & 46,41 & 26,53 & 14,12 & $29,02^{\mathrm{a}}$ \\
\hline Ayam & 22,79 & 11,39 & 16,37 & $16,85^{\mathrm{a}}$ \\
\hline Rerata & $22,65^{\mathrm{a}}$ & $14,66^{\mathrm{a}}$ & $14,46^{\mathrm{a}}$ & $(-)$ \\
\hline
\end{tabular}

Keterangan: Angka superscript pada baris dan kolom yang diikuti dengan huruf yang sama tidak berbeda nyata menurut uji DMRT $\alpha 5 \%$. (-) Tidak terjadi interaksi antar faktor.

\subsection{Pembahasan}

Secara umum dapat dilihat bahwa pemberian bokashi berbahan dasar faces kambing memberikan produksi daun segar dari rumput yang paling berat. Hal ini disebabkan karena pemberian bokashi berbahan dasar faces kambing menciptakan kondisi tanah yang lebih ideal bagi pertumbuhan rumput seperti suhu tanah yang lebih rendah sehingga kadar lengasnya lebih tinggi dan $\mathrm{pH}$ tanah yang lebih mendekati netral. Kondisi lingkungan yang baik menghasilkan pertumbuhan tanaman juga lebih baik berupa tanaman yang lebih tinggi, jumlah anakan dan jumlah daun yang lebih banyak sehingga daun yang segar maupun yang telah dikeringkan tetap lebih berat. Pertumbuhan ini juga didukung oleh kondisi akar yang lebih baik berupa akar segar maupun kering yang lebih berat sebagai akibat pemberian bokashi dengan bahan dasar faces kambing.

Rumput Stenotaphrum secundatum adalah rumput yang menghasilkan daun segar maupun daun kering yang paling berat. Walaupun rumput Stenotaphrum secundatum berukuran paling pendek dengan jumlah anakan yang paling sedikit tetapi diduga bahwa rumput jenis Stenotaphrum secundatum memiliki struktur yang lebih padat sehingga menghasilkan daun yang lebih berat baik berupa daun segar maupun bahan kering.

\section{Simpulan}

Interaksi jenis bokashi dan jenis rumput hanya berpengaruh nyata terhadap berat volume tanah sedangkan pada parameter lain yang diamati tidak terjadi pengaruh interaksi. Jenis bokashi berpengaruh nyata terhadap parameter kadar lengas tanah, $\mathrm{pH}$ tanah, berat segar daun, berat kering daun, dan berat segar akar, sedangkan jenis rumput tidak berpengaruh nyata terhadap semua parameter yang diamati. Pemberian bokashi berbahan dasar faces kambing memberikan produksi rumput berupa daun segar yang paling berat (110,82 g), sedangkan jenis rumput yang memiliki produksi daun segar yang paling berat adalah rumput Stenotaphrum secundatum yakni 78,03 g.

\section{Pustaka}

Gomez, K.A. \& Gomez, A.A. 1984. Statistical Procedures for Agricultural Research. Kefamenanu: John Wiley \& Sons.

Higa, T. \& James, F. 1997. Effective Microorganism (EM4). Dimensi Baru. Kyusei Nature Farming Societies, 2.

Kusuma, M.E. 2012. Pengaruh Beberapa Jenis Pupuk Kandang terhadap Kualitas Bokashi. Jurnal Ilmu Hewani Tropika (Journal of Tropical Animal Science), 1(2): 41-46.

Kusuma, M.E. 2013. Pengaruh Pemberian Bokashi terhadap Pertumbuhan Vegetatif dan Produksi Rumput Gajah (Pennisetum purpureum). Jurnal Ilmu Hewani Tropika (Journal of Tropical Animal Science), 2(2): 40-45.
Musayyanah 2009. Pengaruh Pemberian Pupuk Bokashi terhadap Pertumbuhan Tanaman Sawi (Brassica juncea L.). [Skripsi] Malang: Universitas Islam Negeri Maulana Malik Ibrahim.

Priyanto, D. 2016. Strategi Pengembalian Wilayah Nusa Tenggara Timur sebagai Sumber Ternak Sapi Potong. Jurnal Penelitian dan Pengembangan Pertanian, 35(4): 167-178.

Santoso 1994. Komposisi Zat Gisi Buah Tomat. Jakarta: Penebar Swadaya.

Steel, R.G.D. \& Torrie, J.H. 1981. Principles \& Procedures of Statistics. 2 ed. New York: McGraw-Hill.

Sudarmono, A.S. 2008. Sapi Potong. Jakarta: Penebar Swadaya.

Sutanto, R. 2002. Penerapan Pertanian Organik. Yogyakarta: Kanisius.

Tata, I. 2000. Menggugat Revolusi Hijau Generasi Pertama. Yayasan Tirta Karangsari. Pestisida Action Network (PAN-Indonesia) dan Yayasan Kehati. 